\title{
WASL Gene
}

National Cancer Institute

\section{Source}

National Cancer Institute. WASL Gene. NCI Thesaurus. Code C113224.

This gene plays a role in actin polymerization. 